\title{
Construction of the intermediate vector pVBG2307 by incorporating vital elements of expression vectors pBI121 and pBI221
}

\author{
S.S. Ahmed ${ }^{1}$, Z.-H. Gong ${ }^{1}$, J.-J. Ji', Y.-X. Yin ${ }^{1}$, H.-J. Xiao' ${ }^{1}$ M.A. Khan ${ }^{1,2}$, \\ A. Rehman ${ }^{1}$ and I. Ahmad ${ }^{1}$ \\ ${ }^{1}$ College of Horticulture, Northwest A\&F University, Shaanxi, Yangling, \\ P.R. China \\ ${ }^{2}$ PMAS-Arid Agriculture University, Rawalpindi, Pakistan \\ Corresponding author: Z.-H. Gong \\ E-mail: zhgong@nwsuaf.edu.cn \\ Genet. Mol. Res. 11 (3): 3091-3104 (2012) \\ Received January 30, 2012 \\ Accepted April 18, 2012 \\ Published August 31, 2012 \\ DOI http://dx.doi.org/10.4238/2012.August.31.7
}

\begin{abstract}
Molecular chaperones of plasmid pBI121 carrying CaMV35S promoter and a nucleotide sequence of plasmid pBI221 were inserted into plasmid pCAMBIA2300 to construct an intermediate vector: pVBG2307. This novel vector pVBG2307 contains a greatly expanded multiple cloning site with an adjacent imported CaMV35S promoter sequence. This vector allows controlled transformation of DNA in both Escherichia coli and Agrobacterium tumefaciens. Cloned $P G$, orf456, ipt genes and $E 8$, a fruiting promoter, were amplified by PCR of cDNA libraries of Capsicum annum and Lycopersicon esculentum and were then transferred into vector pVBG2307. The viability of this vector was demonstrated, as it regulated $P G$, orf456, ipt and E8 genes in E. coli and could be transferred into Agrobacterium strain EHA105-4.
\end{abstract}

Key words: pBI121; pBI221; pCAMBIA2300; pVBG2307; $P G$ gene; E8 promoter 


\section{INTRODUCTION}

Crop improvement against physiological aging is an inevitable step to be taken around the world. Horticultural commodities are a mainstay not only for fulfilling food demands but also for the alleviation of poverty among people in the entire world (AVRDC, 2005). Pepper and tomato are the most valuable horticultural commodities all over the world, where they are involved in many significant aspects of human diet and health, serving in culinary, nutritional, medicinal, pharmaceutical, and therapeutic uses, and many other food processing industries (Pruti and Sharma, 1998; Anonymous, 2003; Kothari et al., 2010).

$E 8$ is an ethylene biosynthesis-related gene that was first cloned from tomato (Solanum lycopersicum cv. VFNT Cherry) (Broglie et al., 1986; Holdsworth et al., 1987; Lincoln et al., 1987; McGarvey et al., 1992; Zhao et al., 2009). The transcription of the $E 8$ gene is induced by ethylene and activated at the beginning of fruit ripening. Expression of the $E 8$ gene is spatially and temporally regulated in mature tomato fruit (Deikman and Fischer, 1988). Smith et al. (1990) and Wang et al. (2000) reported that fruit ripening is a complex, genetically programmed process, involving increases in respiration and ethylene production, changes in color and flavor, and softening. Fischer and Bennett (1991) and Ahmed et al. (2011) reviewed that fruit softening is associated with structural changes in the cell wall, including reduction in the size of hemicellulose, loss of galactose side-chains, and solubilization and depolymerization of pectin by the influence of one of the hydrolytic enzymes, polygalacturonase (PG).

Cytoplasmic male sterility (CMS) in peppers is a maternally inherited trait that leads to the failure to produce functional pollen. Schnable and Wise (1998) identified the gene associated with the CMS trait in the mitochondrial genome. Some years later, Kim et al. (2007) reported that orf456 is a strong candidate gene for determining the male-sterile phenotype of CMS in chili pepper.

Cytokinins belong to a class of plant hormones first noted as able to promote plant cell division (Miller et al., 1956; Guivarc'h et al., 2002). One approach to investigating the function of cytokinins is the generation of transgenic plants overproducing cytokinins by expressing the Agrobacterium T-DNA-derived ipt gene, which encodes an isopentenyltransferase that catalyzes the rate-limiting step of cytokinin biosynthesis (Akiyoshi et al., 1984; Barry et al., 1984).

Crop improvement by means of genetic engineering has become the most authentic, efficient and time-saving approach in the recent era of the food revolution (Kahl and Winter, 1995). Agrobacterium-mediated transformation by means of different targeted expression vectors in numerous plant species has gained some outstanding reputation and has become the most favorite choice for the researchers to establish control over different genes.

The present studies aimed at achieving some landmarks in molecular research and introduce a novel expression vector, pVBG2307, which may help to establish control over the expression and manipulation of different genes such as $P G$, orf 456 and ipt and promoters such as $E 8$, extensively involved in the fruit aging process.

\section{MATERIAL AND METHODS}

\section{Plant material}

Tomato (Lycopersicon esculentum) and pepper (Capsicum annum) fruits of approximately uniform size and color and free from foreign contamination were collected and used 
for RNA extraction followed by the construction of cDNA libraries.

\section{Binary expression vectors}

Binary expression vectors pBI121 and pBI221 (Chen et al., 2003) were manipulated into the vector pCAMBIA2300 (Xu et al., 2010) towards developing the novel vector pVBG2307. Primarily, there are eGFP and GUS reporter genes present in the vector pBI221 with ampicillin resistance existing at the ApaLI, KpnI, PstI, SacI, ScaI, and XbaI loci. On the other hand, the vector pBI121 is devoid of these elements.

\section{Construction of cDNA library}

Fruit pericarp was thoroughly ground in liquid nitrogen and total RNA was extracted. Total RNA was extracted with an Invisorb-Spin Plant-RNA Mini kit (Invitek, Berlin, Germany). This was then treated with RNase-free DNase-I (Xue and Loveridge, 2004) to remove possible contaminating DNA. The remaining RNA was reverse-transcribed using oligo(dT)18 primers and a RevertAid First-Strand cDNA Synthesis kit. The cDNA was obtained using the M-MLV reverse transcriptase kit (Promega, Madison, WI, USA). Samples were reverse-transcribed in situ by adding a real-time mix to give a total volume of $20 \mu \mathrm{L}$. Each tube contained $1 \mu \mathrm{g} 4.5 \mu \mathrm{L}$ RNA and $0.5 \mu \mathrm{g} / \mu \mathrm{L}$ oligo(dT) 18 primer. Reverse transcription proceeded for 60 min at $42^{\circ} \mathrm{C}$ before the reaction was terminated by heating to $72^{\circ} \mathrm{C}$ for $10 \mathrm{~min}$.

\section{PCR amplification of the $P G$ gene}

A set of specially designed primers including the enzyme cutting sites of SmaI and $X b a$ I were used for amplifying both $P G$ forward (5'-3') and reverse (5'-3') (Table 1). A reaction mixture of approximately $25 \mu \mathrm{L}(0.5 \mu \mathrm{L}$ pepper cDNA template, $2.5 \mu \mathrm{L} 10 \mathrm{X}$ PCR buffer, 0.2 $\mu \mathrm{L} 5 \mathrm{U} / \mu \mathrm{L}$ Taq DNA polymerase, $0.5 \mu \mathrm{L} 10 \mathrm{mM}$ dNTP mixture, $19.3 \mu \mathrm{L} \mathrm{ddH}_{2} \mathrm{O}$, and $1 \mu \mathrm{L}$ each of PG-F and PG-R) was used for conducting PCR. Amplification consisted of 30 cycles of $45 \mathrm{~s}$ at $94^{\circ} \mathrm{C}$ (denaturation), $60 \mathrm{~s}$ at $54^{\circ} \mathrm{C}$ (primer annealing) and $120 \mathrm{~s}$ at $72^{\circ} \mathrm{C}$ (extension) (Giorno et al., 2010). The optical density of the electrophoretic bands of $P G$ genes was determined with a gel-imaging analysis system (Syngene, Cambridge, UK). Each treatment was performed 3 times. Primer sequences of the gene and its expected amplified product size are given in Table 1.

Table 1. Primer sequences of the genes used for PCR amplification along with expected amplified bands.

\begin{tabular}{|c|c|c|c|}
\hline Gene & Primer & Primer sequence & Amplified size (bp) \\
\hline \multirow[t]{2}{*}{$P G-F$} & PG-F1 & 5'-CTAGTCTAGAATTATCATGTCTATCCAAAAGATTA-3' & 1143 \\
\hline & PG-R1 & 5'-TCCCCCGGGCACCACATTTTTCACTTTAACT-3' & \\
\hline \multirow[t]{2}{*}{$P G-R$} & PG-F2 & 5'-TCCCCCGGGATTATCATGTCTATCCAAAAGATTA-3' & 1141 \\
\hline & PG-R2 & 5'-CTAGTCTAGACACCACATTTTTCACTTTAACT-3' & \\
\hline \multirow[t]{2}{*}{ E8 } & E8-F & 5'-GACCTTCTTTTGCACTGTGAATGATT-3' & 1074 \\
\hline & E8-R & 5'-CTAGAAGGAATTTCACGAAATCGGC-3' & \\
\hline \multirow[t]{2}{*}{ orf456 } & orf-F & 5'-ATGCCCAAAAGTCCCATGTAT-3' & 450 \\
\hline & orf-R & 5'-TTACTCGGTTGCTCCATTGT-3' & \\
\hline \multirow[t]{2}{*}{ ipt } & IPT-F & 5'-ATGGATCTTAGACTTATTTTTGGAC-3' & 750 \\
\hline & IPT-R & 5'-CTAATACATTCCAAATGGATGTCC-3' & \\
\hline
\end{tabular}




\section{PCR amplification of the orf 456 gene}

A set of specially designed primers including the enzyme cutting sites of $K p n \mathrm{I}$ and SacI were used for amplifying the orf456 gene. A PCR mixture of $25 \mu \mathrm{L}$ contained $(0.5 \mu \mathrm{L}$ pepper cDNA template, $2.5 \mu \mathrm{L}$ 10X PCR buffer, $0.2 \mu \mathrm{L} 5 \mathrm{U} / \mu \mathrm{L}$ Taq DNA polymerase, $0.5 \mu \mathrm{L}$ $10 \mathrm{mM}$ dNTP mixture, $19.3 \mu \mathrm{L} \mathrm{ddH_{2 }} \mathrm{O}$, and $1 \mu \mathrm{L}$ each of orf456-F and orf456-R) was used for conducting PCR. Amplification consisted of 30 cycles of $45 \mathrm{~s}$ at $94^{\circ} \mathrm{C}$ (denaturation), $60 \mathrm{~s}$ at $52^{\circ} \mathrm{C}$ (primer annealing) and $50 \mathrm{~s}$ at $72^{\circ} \mathrm{C}$ (extension) (Giorno et al., 2010). The optical density of the electrophoretic bands of the orf456 gene was determined with a gel-imaging analysis system (Syngene). Each treatment was performed 3 times. Primer sequences of the gene and its expected amplified product size are given in Table 1.

\section{PCR amplification of the ipt gene}

A set of specially designed primers including the enzyme cutting sites of Bam $\mathrm{HI}$ and $\mathrm{SacI}$ were used for amplifying the ipt gene. A reaction mixture of approximately $25 \mu \mathrm{L}(0.5$ $\mu \mathrm{L}$ pepper cDNA template, $2.5 \mu \mathrm{L} 10 \mathrm{X}$ PCR buffer, $0.2 \mu \mathrm{L} 5 \mathrm{U} / \mu \mathrm{L}$ Taq DNA polymerase, 0.5 $\mu \mathrm{L} 10 \mathrm{mM}$ dNTP mixture, $19.3 \mu \mathrm{L} \mathrm{ddH_{2 }} \mathrm{O}$, and $1 \mu \mathrm{L}$ each of ipt-F and ipt-R) was used for conducting PCR. Amplification consisted of 30 cycles of $45 \mathrm{~s}$ at $94^{\circ} \mathrm{C}$ (denaturation), $60 \mathrm{~s}$ at $51^{\circ} \mathrm{C}$ (primer annealing) and $80 \mathrm{~s}$ at $72^{\circ} \mathrm{C}$ (extension) (Giorno et al., 2010). The optical density of the electrophoretic bands of the ipt gene was determined with a gel-imaging analysis system (Syngene). Each treatment was performed 3 times. Primer sequences of the gene and its expected amplified product size are given in Table 1.

\section{PCR amplification of the $E 8$ promoter}

The concentration of tomato genomic cDNA was adjusted to $20 \mathrm{ng} / \mu \mathrm{L}$ for the PCR template, and PCR was then performed using ExTaq DNA polymerase (Takara, Japan). A PCR mixture of $25 \mu \mathrm{L}$ contained $2 \mu \mathrm{L}$ template, $2.5 \mu \mathrm{L}$ 10X PCR buffer $(100 \mathrm{mM}$ Tris-HCl buffer, $500 \mathrm{mM} \mathrm{KCl}, 0.01 \%$ gelatin), $1.5 \mu \mathrm{L} 25 \mathrm{mM} \mathrm{MgCl}_{2}, 1.5 \mu \mathrm{L} 2.5 \mathrm{mM}$ dNTPs (Takara), $1 \mu \mathrm{L}$ $10 \mu \mathrm{M}$ PCR primers (E8-F and E8-R), $0.3 \mu \mathrm{L} 5 \mathrm{U} / \mu \mathrm{L}$ ExTaq DNA polymerase and $15.2 \mu \mathrm{L}$ sterilized $\mathrm{ddH}_{2} \mathrm{O}$. The program was initiated with a hot start at $94^{\circ} \mathrm{C}$ for 3 min, followed by 35 cycles of $94^{\circ} \mathrm{C}$ for $45 \mathrm{~s}, 54^{\circ} \mathrm{C}$ for $45 \mathrm{~s}$ and $72^{\circ} \mathrm{C}$ for $1.5 \mathrm{~min}$, and finally $72^{\circ} \mathrm{C}$ for $8 \mathrm{~min}$. PCR products were electrophoresed on a $2.0 \%(\mathrm{w} / \mathrm{v})$ agarose gel with ethidium bromide in $1 \mathrm{X}$ TAE buffer, and photographs were taken under ultraviolet light. Each treatment was performed 3 times. Primer sequences of the $E 8$ gene and its expected amplified product size are given in Table 1.

\section{Cloning and sequencing of $P G-F, P G-R$, orf456, and ipt genes and the $E 8$ promoter}

All PCR products were purified using a gel extraction kit (Watson Biotechnologies Inc., Shanghai, China), cloned into pGEM-T Easy (Promega) and sequenced with an ABI Sequencer 3700 (Shanghai, China). After the validation of sequences with the use of the BioEdit version 5.0.6 software the correct clones were subsequently transformed into Escherichia coli by means of an improved freezing and thawing method (Deikman et al., 1998; Xu et al., 2005). 


\section{Construction of the pVBG2307 and other allied vectors}

Plant expression vectors containing the $P G$, orf 456 and ipt coding sequences controlled by the preferential core CaMV35S and $E 8$ promoters were constructed as follows. The foreign CaMV35S promoter fragment was cleaved from vector pBI121 with HindIII and $\mathrm{XbaI}$ and ligated into vector pCAMBIA2300 (Xu et al., 2010), the resulting plasmid was confirmed by sequencing and enzyme digestion (Figure 1).
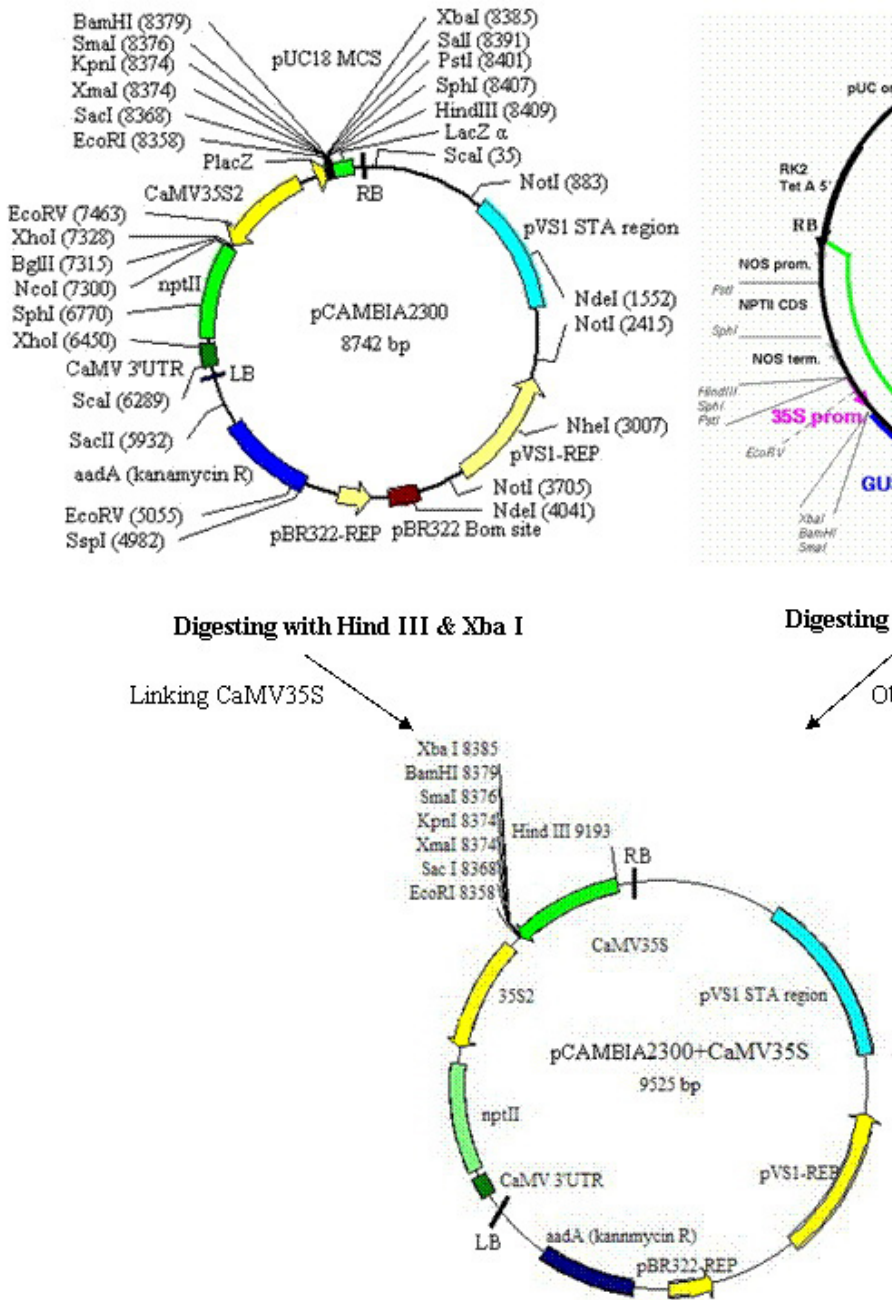

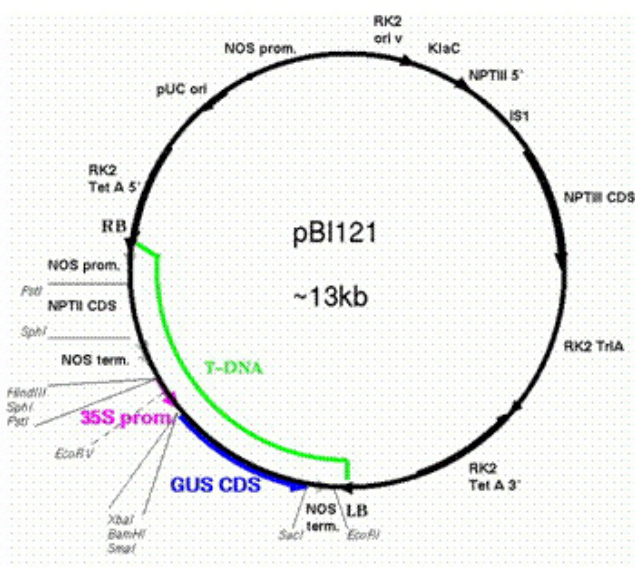

Digesting with Hind III \& Xha I

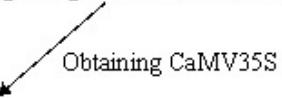

Figure 1. Vector pCAMBIA2300 was used as a precursor of vector pVBG2307, as the cleaved CaMV35S promoter from vector pBI121 was linked into it by using the enzymes HindIII and $\mathrm{XbaI}$.

As pCAMBIA2300 is devoid of NOS terminal on its right border, a foreign NOS terminal was cleaved from vector pBI221 with EcoRI and SacI and ligated into pCAMBIA2300. 
The resulting plasmid was confirmed by sequencing and enzyme digestion and given the name pVBG2307 (Plant Vegetable Breeding and Genetics) (Figures 2 and 3). Four other different types of plant expression vectors, pVBG2307+PG-F, pVBG2307+PG-R, pVBG2307+E8+PG$\mathrm{F}$, and pVBG2307+E8+PG-R (Figures 4-7), were successfully produced by insertion of the $E 8$ promoter and $P G$ gene fragments from pGEM-T into pBluescript $I I$ SK and then pCAMBIA2300 by using the EcoRI, PstI, SalI, SmaI, and XbaI sites following the downstream pathway of different appropriate restriction enzymes. Plasmids carrying the orf456 and ipt genes were developed by using the KpnI, SacI, and BamHI enzymes (data not shown). All vectors were confirmed by performing PCR, sequencing and restriction enzyme digestion.

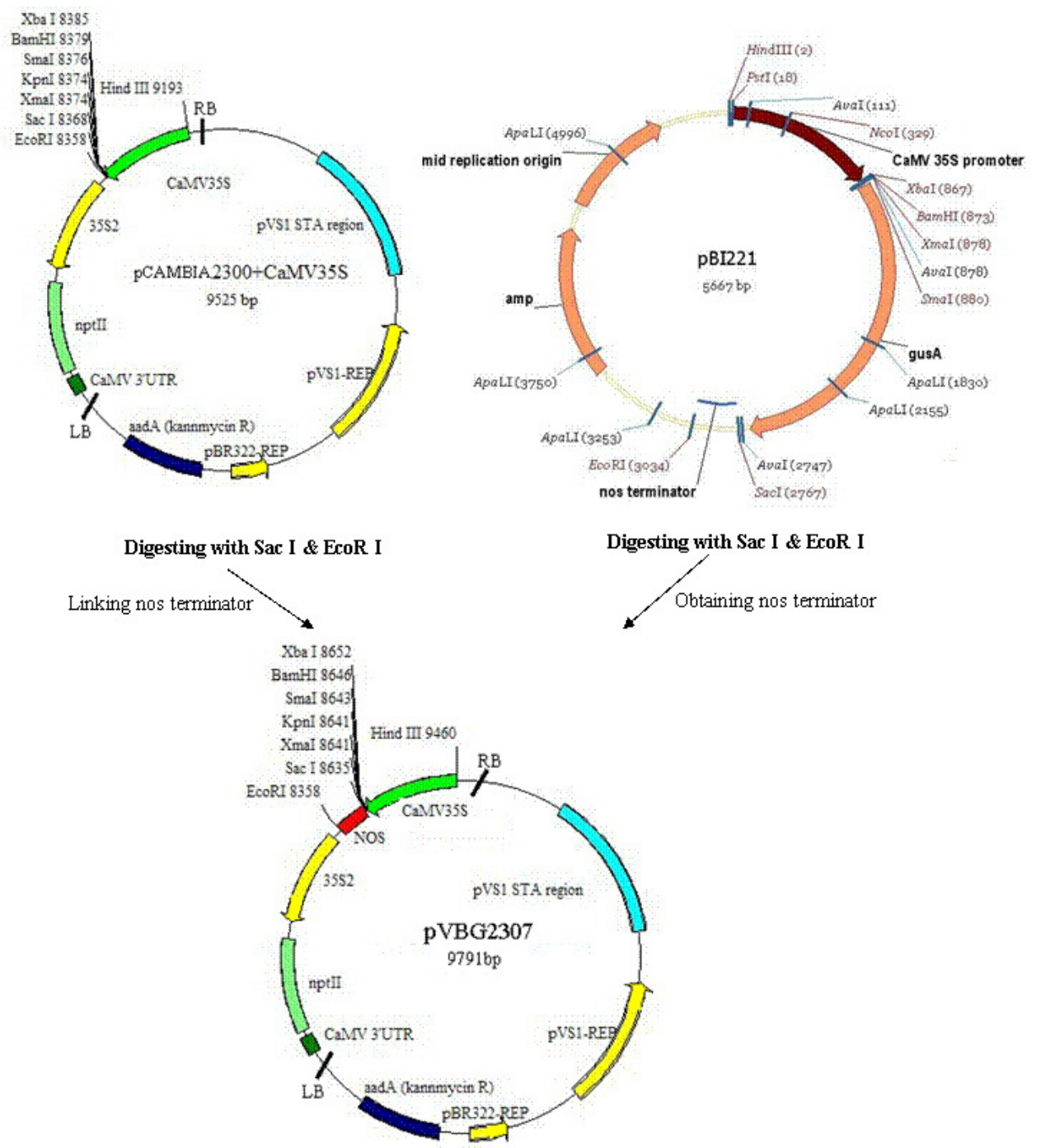

Figure 2. Vector pVBG2307 was developed finally by adding cleaved NOS terminal from the vector pBI221 into pCAMBIA2300 using the enzymes SacI and EcoRI. 


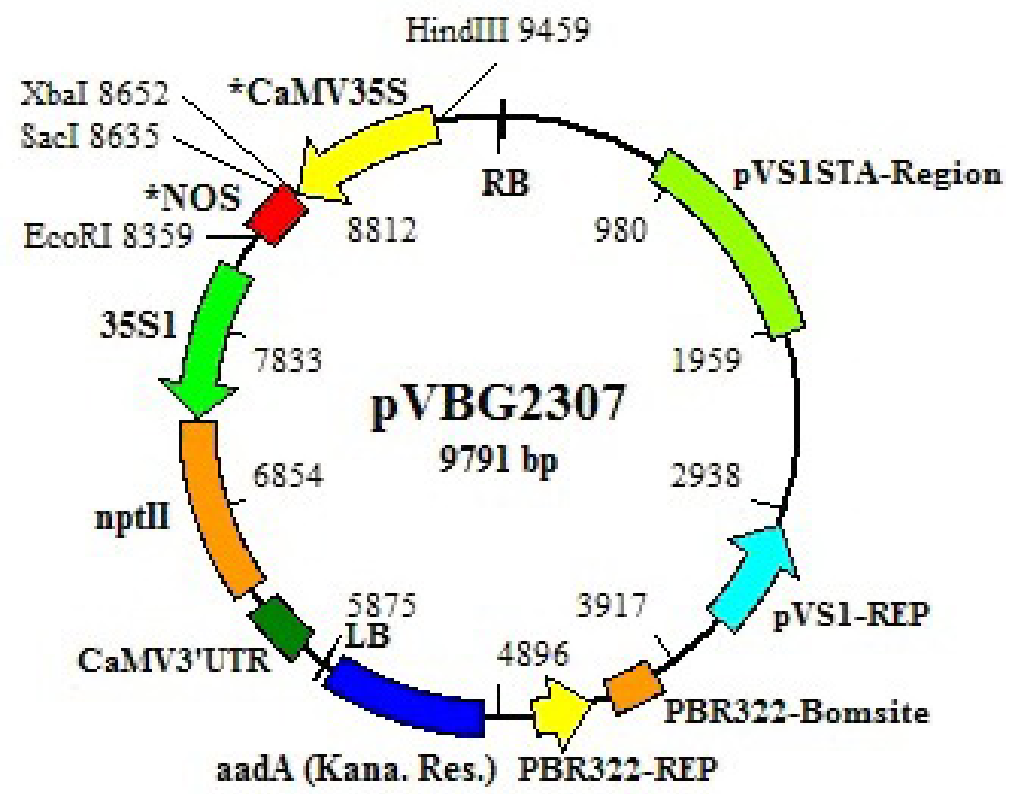

Figure 3. Schematic map of vector pVBG2307 carrying imported CaMV35S promoter and NOS terminal. * Specially cleaved CaMV35S promoter and NOS terminal from vector pBI121 and pBI221, respectively.

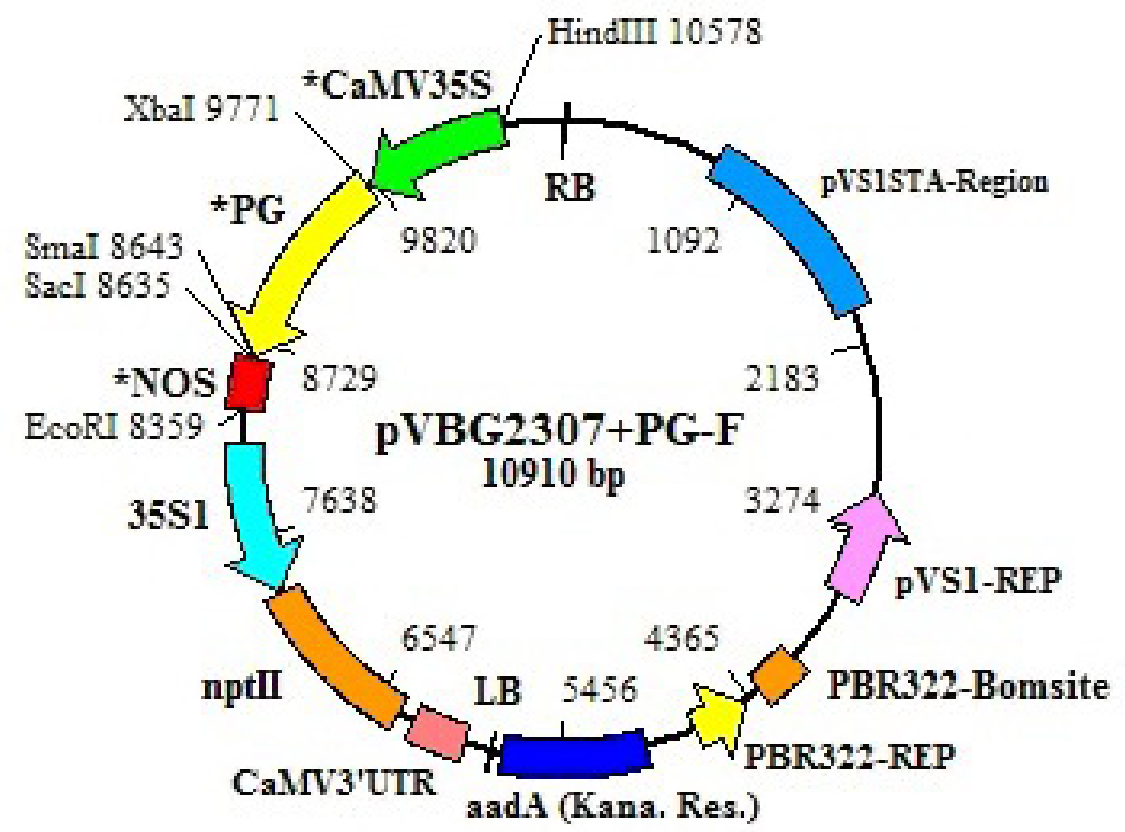

Figure 4. Schematic map of vector pVBG2307 carrying imported CaMV35S promoter, $P G-F$ gene and NOS terminal. *Specially cleaved CaMV35S promoter; cloned $P G-F$ and NOS terminal. 


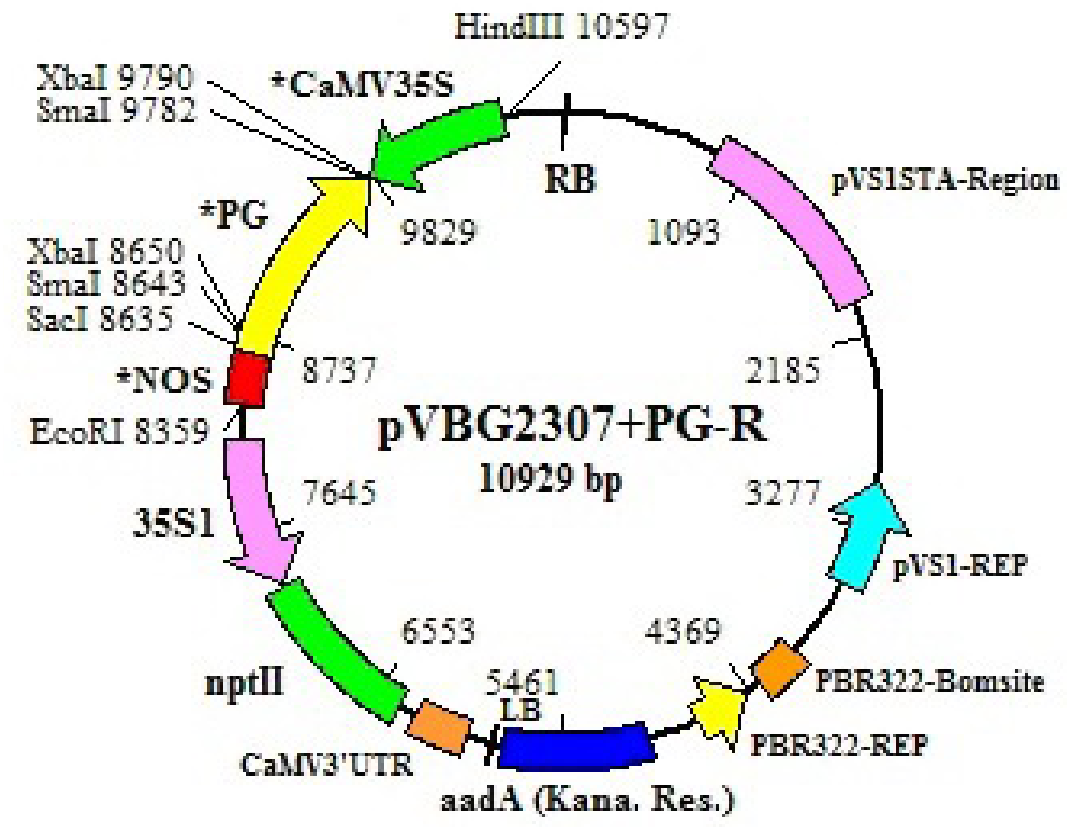

Figure 5. Schematic map of vector pVBG2307 carrying imported CaMV35S promoter, $P G-R$ gene and NOS terminal. *Specially cleaved CaMV35S promoter; cloned $P G-R$ and NOS terminal.

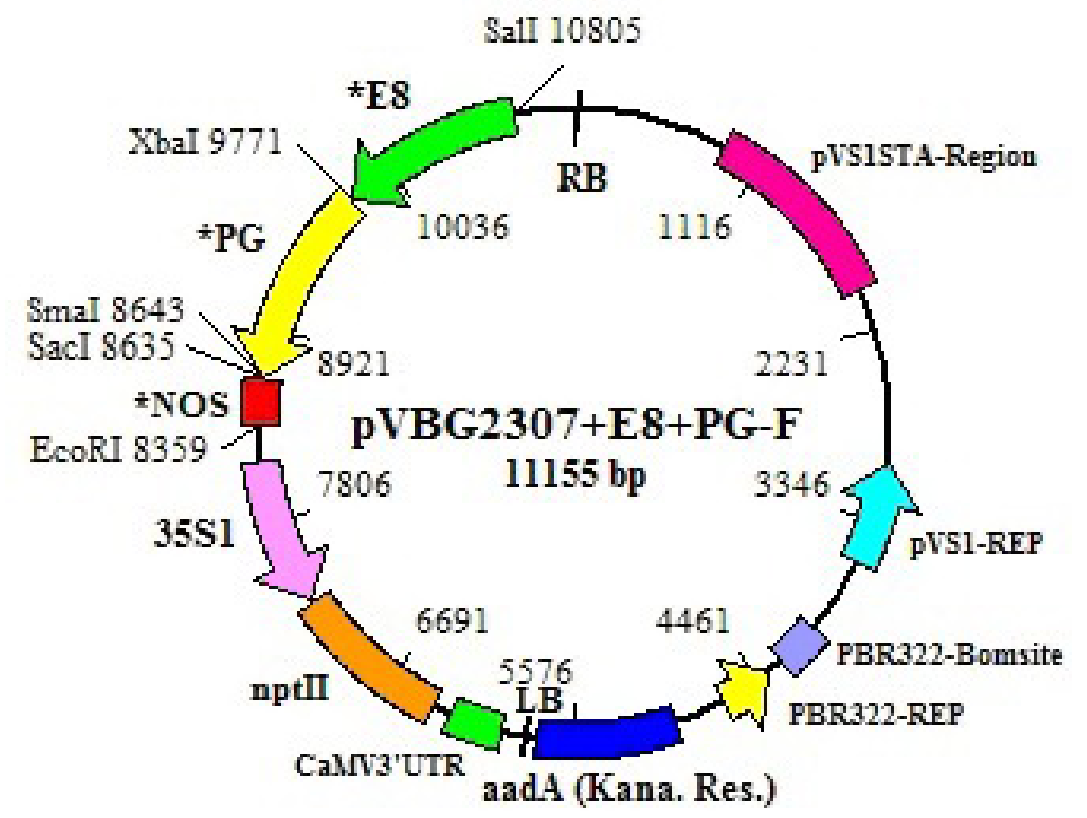

Figure 6. Schematic map of vector pVBG2307 carrying substituted $E 8$ special fruit promoter, $P G-F$ gene and NOS terminal. *Specially cloned $E 8$ fruit promoter and $P G-F$ gene with NOS terminal. 


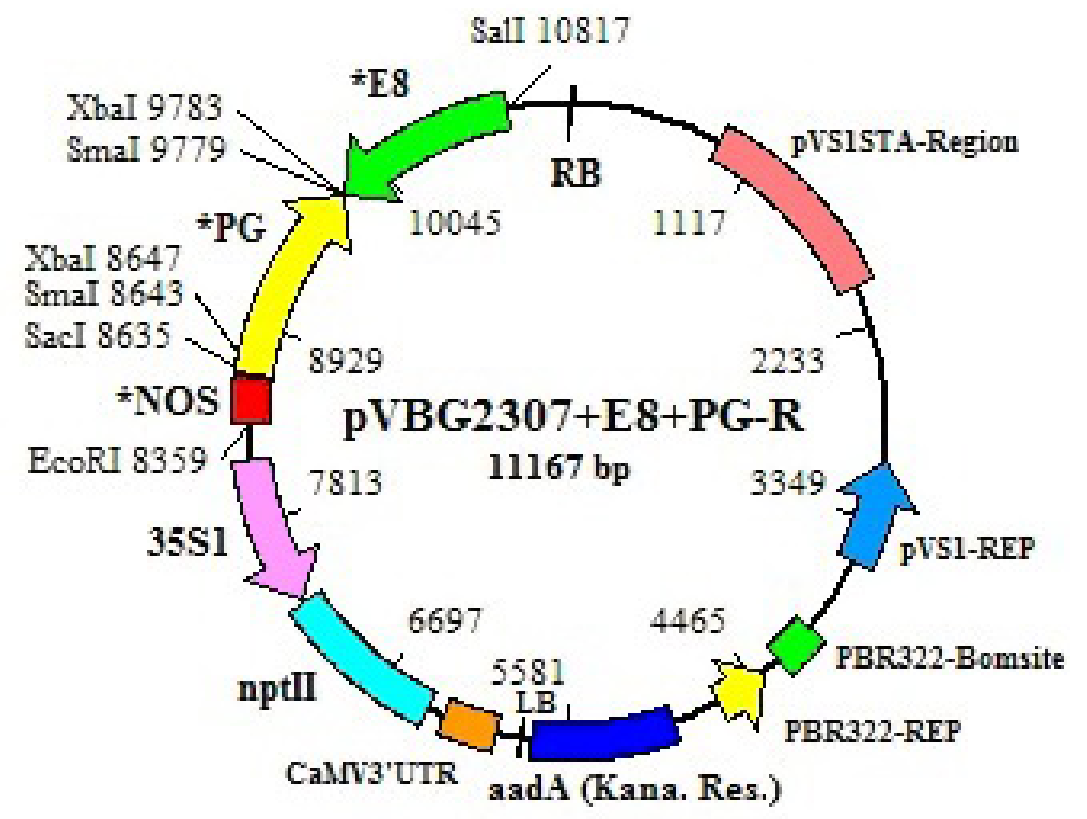

Figure 7. Schematic map of vector pVBG2307 carrying substituted $E 8$ special fruit promoter, $P G-R$ gene and NOS terminal. *Specially cloned $E 8$ fruit promoter and $P G-R$ gene with NOS terminal.

\section{RESULTS}

\section{Amplification of $P G$, orf 456 , ipt genes and the $E 8$ promoter}

A PCR product of the $P G$ gene of approximately $1.1 \mathrm{~kb}$ was amplified in both forward and reverse direction (Chen et al., 2010) at ripening stages of pepper (Figure 8A and B) and cloned into pGEM-T Easy (Promega). Subsequently, the $P G$ gene was successfully inserted into pVBG2307, and the resultant plasmid was confirmed by performing PCR and enzyme digestion (Figure 9A).

A PCR product of the orf 456 gene of approximately $0.45 \mathrm{~kb}$ was amplified (Kim et al., 2007) and cloned into pGEM-T Easy (Promega). Subsequently, the orf456 gene was successfully inserted into pVBG2307, and the resultant plasmid was confirmed by performing PCR and enzyme digestion (Figure 8E).

A PCR product of the ipt gene of approximately $0.75 \mathrm{~kb}$ was amplified (Guivarc'h et al., 2002) and cloned into pGEM-T Easy (Promega). Subsequently, the ipt gene was successfully inserted into pVBG2307, and the resultant plasmid was confirmed by performing PCR and enzyme digestion (Figure 9E).

A PCR product of the $E 8$ promoter of approximately $1.07 \mathrm{~kb}$ was amplified (Zhao et al., 2009) at the ripening stages of tomato (Figure 8C) and cloned into pGEM-T Easy (Promega). Subsequently, the $E 8$ promoter was successfully ligated into pBluescript $I I$ SK and then inserted into pVBG2307 (Figure 3), and the resultant plasmid was confirmed by performing PCR and enzyme digestion (Figure 8C). 


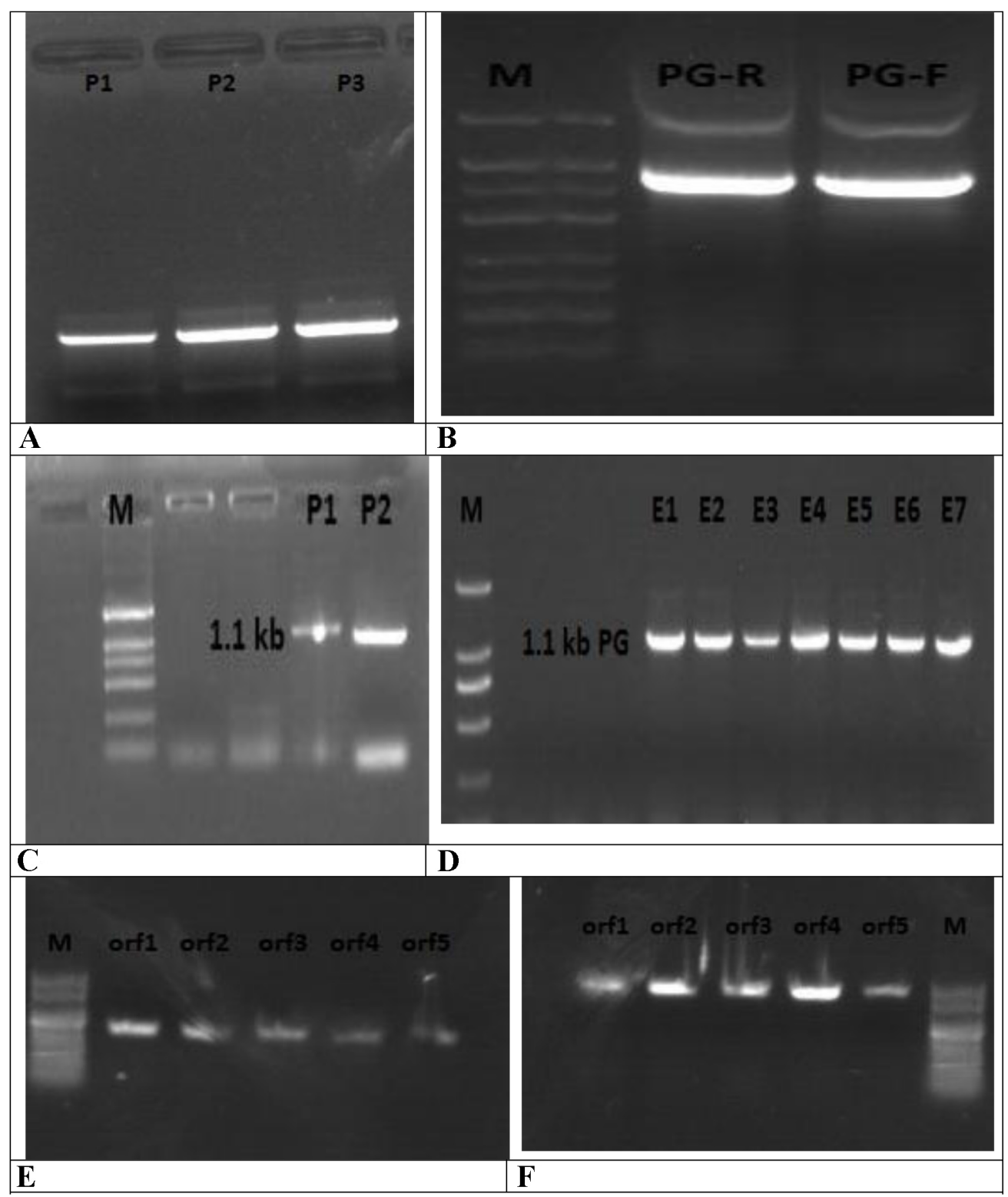

Figure 8. A. and B. PCR product of the PG gene. C. PCR product of the E8 promoter. D. Amplified $P G-F+$ pVBG2307 in EHA105-4. E. PCR of the orf456 gene. F. Amplified orf456 + pVBG2307 from EHA105-4.

\section{Cleavage of the CaMV35S promoter}

The imported CaMV35S promoter fragment (Tanaka et al., 2011) was cleaved from 


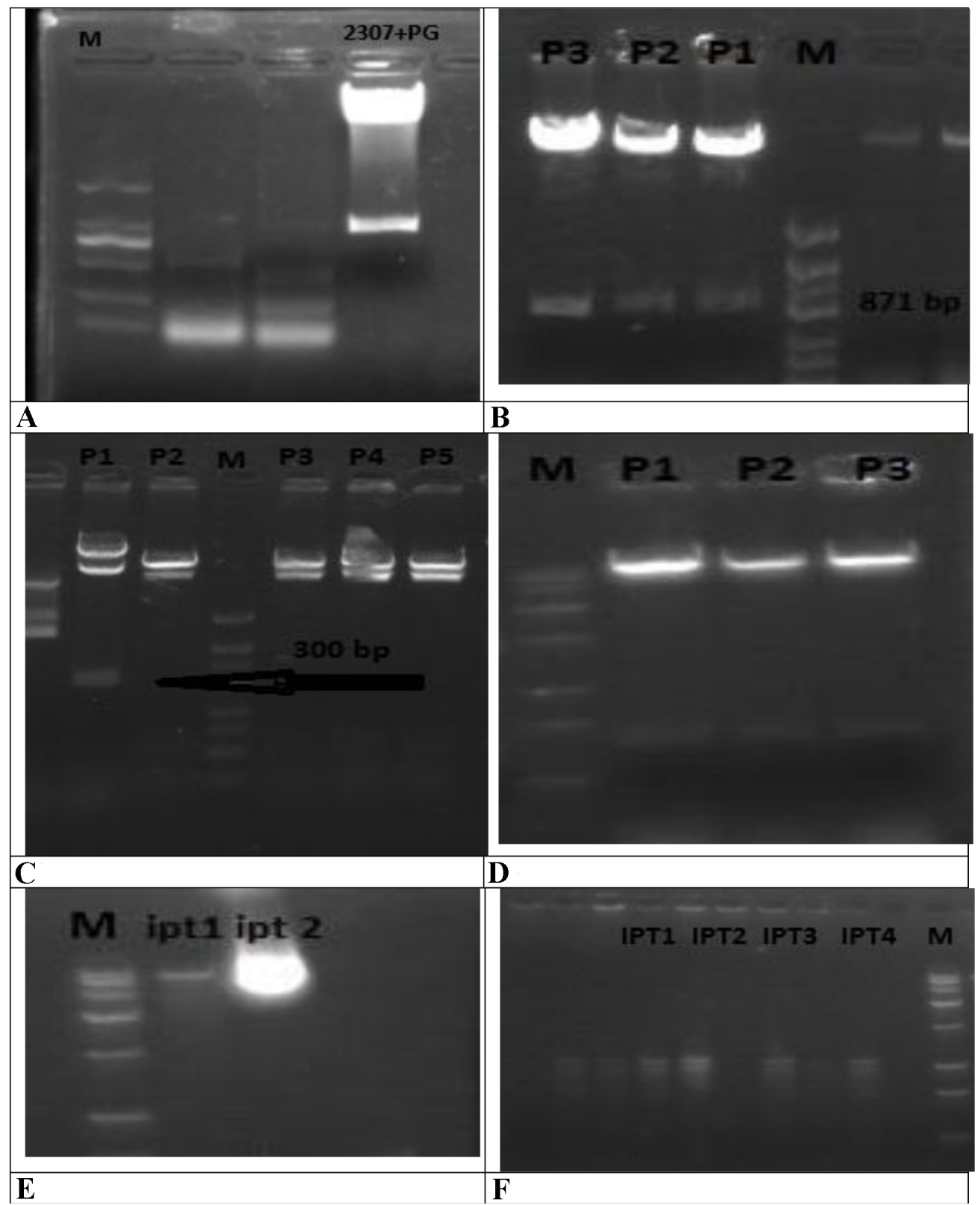

Figure 9. A. Confirmation of $P G$ ligation in pVBG2307 with the digestion of enzymes $S m a \mathrm{I}$ and $X b a \mathrm{I}$. B. Confirmation of ligated CaMV35S from pVBG2307 by double digestion with HindIII and XbaI. C. Confirmation of ligated NOS terminal from pVBG2307. D. Cleavage of CaMV35S from pBI121 with HindIII and XbaI. E. PCR product of the ipt gene. F. Amplified ipt + pVBG2307 from EHA105-4.

vector pBI121 using the enzymes HindIII and $X b a \mathrm{I}$ (Figure 1) and successfully incorporated into pCAMBIA2300 (Figure 1). 


\section{Cleavage of NOS terminal}

The absence of NOS terminal (Ishikawa et al., 2011) on the right border of pCAMBIA2300 paved the way for extracting the NOS element from vector pBI221 by the action of EcoRI and $S a c I$ and successfully ligated into pCAMBIA2300 (Figure 1).

\section{Validation of vector $\mathrm{pVBG} 2307$}

The utility of vector pVBG2307 was tested by successful cloning of promoterless $P G$, orf456, ipt, and $E 8$ from pGEM-T and pBluescript $I I$ SK downstream of the imported CaMV35S promoter element among the BamHI, KpnI, SacI, SmaI, and XbaI sites of vector pVBG2307, generating the plasmids pVBG2307+PG-F, pVBG2307+PG-R, pVBG2307+E8+PG-F, pVBG2307+E8+PG-R, pVBG2307+orf456, and pVBG2307+ipt. All plasmids were successfully regulated and transformed into E. coli and Agrobacterium tumefaciens strain EHA105-4 by means of an improved freezing and thawing method (Chen et al., 2003; Xu et al., 2005). Hence, their successful cloning was not only demonstrated by obtaining the amplified $P G$, orf 456 and ipt genes and $E 8$ promoter from the strain EHA105-4 (Sambrook and Russell, 2000) but also conducting the restriction enzyme digestion (Figure 9A-D and $\mathrm{F}$ and Figure 8D and F).

\section{DISCUSSION}

In the field of genomic transformation, expression vectors play a crucial role, and we expected that the vector pVBG2307 could be considered as a new hope. The novel vector pVBG2307 provides unique sites in the multiple cloning sites for 13 different restriction enzymes (Tables 2 and 3) to allow greater manipulation of DNA fragments; moreover, pVBG2307 possesses an additional plant promoter in the form of CaMV35S, enabling molecular researchers to clone their gene of interest in a broader range. Direct analysis of genes such as $P G$, orf456 and ipt and promoters such as $E 8$ without the need for additional subcloning in the tumor-inducing bacteria EHA105-4 and E. coli provide an excellent example of its significance.

\begin{tabular}{|c|c|c|}
\hline Location & Enzyme name & Site of cloning (bp) \\
\hline \multirow{7}{*}{$\mathrm{RB}$} & Bam $\mathrm{HI}$ & 8379 \\
\hline & SmaI & 8376 \\
\hline & KpnI & 8374 \\
\hline & $X m a \mathrm{I}$ & 8374 \\
\hline & SacI & 8368 \\
\hline & EcoRI & 8358 \\
\hline & PlacZ & 8355 \\
\hline \multirow[t]{6}{*}{ LB } & $X b a \mathrm{I}$ & 8285 \\
\hline & SalI & 8391 \\
\hline & Pst $\mathrm{I}$ & 8401 \\
\hline & SphI & 8407 \\
\hline & HindIII & 8409 \\
\hline & ScaI & 35 \\
\hline
\end{tabular}

$\mathrm{RB}$ and $\mathrm{LB}=$ right and left border of binary vector, respectively. 
Table 3. List of cloned genes, cleaved elements and binary vectors sequenced in pVBG2307, including their cutting sites and sizes.

\begin{tabular}{llcc}
\hline & Cutting sites $\left(5^{\prime}-3^{\prime}\right)$ & Size $(\mathrm{kb})$ & Accession No. \\
\hline$P G-F$ & $X b a \mathrm{I}$, SmaI & 1.14 & FJ596175 \\
$P G-R$ & SmaI, $X b a \mathrm{I}$ & 1.14 & FJ596175 \\
$E 8$ promoter & SalI, $X b a \mathrm{I}$ & 1.07 & AF515784 \\
orf456 & KpnI, SacI & 0.45 & DQ116040 \\
$i p t$ & BamHI, SacI & 0.75 & AE007871 \\
CaMV35S & HindIII, XbaI & 0.82 & AB608312 \\
NOS terminal & EcoRI, SacI & 0.29 & AB537478 \\
pBI121 & HindIII, XbaI & 14.76 & AF485783 \\
pBI221 & EcoRI, SacI & 5.67 & AF502128 \\
pCAMBIA2300 & Included all above & 12.06 & GQ870263 \\
\hline
\end{tabular}

Our findings are in agreement with those of Watson et al. (1996) and Chen et al. (2003), as they used similar molecular demonstrations to validate the usefulness of their expression vectors. The successful cloning of genes such as $P G$, orf 456 and ipt has paved the way for the pVBG2307 for Agrobacterium-mediated transformation. Transformed T-DNA into $E$. coli and $A$. tumefaciens has given the greatest encouragement in the manipulation of the expression of genes of interest and prediction of their functions in various crop species. In the near future, experiments will be conducted to develop transgenic plants by using the vector pVBG2307. On the basis of our results, we can predict some appreciable developments regarding Agrobacterium-mediated transformation in different plant species.

\section{ACKNOWLEDGMENTS}

Research supported by the National Natural Science Foundation of China (\#30571262, \#1000906), the National High Technology Research and Development Program (\#2009AA10Z104-6) and the Shaanxi Province Agriculture Science and Technology Projects (\#2010K01-25-1).

\section{REFERENCES}

Ahmed SS, Gong ZH, Khan MA, Yin YX, et al. (2011). Activity and expression of polygalacturonase vary at different fruit ripening stages of sweet pepper cultivars. Genet. Mol. Res. 10: 3275-3290.

Akiyoshi DE, Klee H, Amasino RM, Nester EW, et al. (1984). T-DNA of Agrobacterium tumefaciens encodes an enzyme of cytokinin biosynthesis. Proc. Natl. Acad. Sci. U. S. A. 81: 5994-5998.

Anonymous (2003). The production and post-harvest handling of sweet pepper in Kenya. Horticultural Crops Development Authority (HCDA), Kenia.

AVRDC (2005). The World Vegetable Centre. Available at [www.avrdc.org/pdf/brief-poverty.pdf]. Accessed July 20, 2011.

Barry GF, Rogers SG, Fraley RT and Brand L (1984). Identification of a cloned cytokinin biosynthetic gene. Proc. Natl. Acad. Sci. U. S. A. 81: 4776-4780.

Broglie KE, Gaynor JJ and Broglie RM (1986). Ethylene-regulated gene expression: molecular cloning of the genes encoding an endochitinase from Phaseolus vulgaris. Proc. Natl. Acad. Sci. U. S. A. 83: 6820-6824.

Chen PY, Wang CK, Soong SC and To KY (2003). Complete sequence of the binary vector pBI121 and its application in cloning T-DNA insertion from transgenic plants. Mol. Breed. 11: 287-293.

Chen RG, Yang RP, Gong ZH, Li DW, et al. (2010). Cloning and sequence analysis of the polygalacturonase gene $C a P G$ in pepper. Acta Bot. Boreal.-Occident. Sin. 30: 1941-1945.

Deikman J and Fischer RL (1988). Interaction of a DNA binding factor with the 5'-flanking region of an ethyleneresponsive fruit ripening gene from tomato. EMBO J. 7: 3315-3320. 
Deikman J, Xu R, Kneissl ML, Ciardi JA, et al. (1998). Separation of cis elements responsive to ethylene, fruit development, and ripening in the 5'-flanking region of the ripening-related E8 gene. Plant Mol. Biol. 37: 1001-1011.

Fischer RL and Bennett AB (1991). Role of cell wall hydrolases in fruit ripening. Annu. Rev. Plant Physiol. 42: 675-703.

Giorno F, Wolters-Arts M, Grillo S, Scharf KD, et al. (2010). Developmental and heat stress-regulated expression of HsfA2 and small heat shock proteins in tomato anthers. J. Exp. Bot. 61: 453-462.

Guivarc'h A, Rembur J, Goetz M, Roitsch T, et al. (2002). Local expression of the ipt gene in transgenic tobacco (Nicotiana tabacum L. cv. SR1) axillary buds establishes a role for cytokinins in tuberization and sink formation. J. Exp. Bot. 53: 621-629.

Holdsworth MJ, Bird CR, Ray J, Schuch W, et al. (1987). Structure and expression of an ethylene-related mRNA from tomato. Nucleic Acids Res. 15: 731-739.

Ishikawa M, Murata T, Sato Y, Nishiyama T, et al. (2011). Physcomitrella cyclin-dependent kinase A links cell cycle reactivation to other cellular changes during reprogramming of leaf cells. Plant Cell 23: 2924-2938.

Kahl G and Winter P (1995). Plant genetic engineering for crop improvement. World J. Microbiol. Biotechnol. 11: 449-460.

Kim DH, Kang JG and Kim BD (2007). Isolation and characterization of the cytoplasmic male sterility-associated orf456 gene of chili pepper (Capsicum annuum L.). Plant Mol. Biol. 63: 519-532.

Kothari SL, Joshi A, Kachhwaha S and Ochoa-Alejo N (2010). Chilli peppers-a review on tissue culture and transgenesis. Biotechnol. Adv. 28: 35-48.

Lincoln JE, Cordes S, Read E and Fischer RL (1987). Regulation of gene expression by ethylene during Lycopersicon esculentum (tomato) fruit development. Proc. Natl. Acad. Sci. U. S. A. 84: 2793-2797.

McGarvey DJ, Sirevag R and Christoffersen RE (1992). Ripening-related gene from avocado fruit: ethylene-inducible expression of the mRNA and polypeptide. Plant Physiol. 98: 554-559.

Miller CO, Skoog F, Okumura FS, Von-Salza MH, et al. (1956). Isolation, structure and synthesis of kinetin, a substance promoting cell division. J. Am. Chem. Soc. 78: 1375-1380.

Pruti JS and Sharma RP (1998). Major Spices of India Crop Management and Post Harvest Technology. In: Chapter IV: Chillies or Capsicum. Indian Council of Agricultural Research Publications and Information Division, New Delhi, 558-670.

Sambrook J and Russell DW (2000). Molecular Cloning: A Laboratory Manual. 3rd edn. CSHL Press, New York.

Schnable PS and Wise RP (1998). The molecular basis of cytoplasmic male sterility and fertility restoration. Trends Plant Sci. 3: 175-180.

Smith CJ, Watson CF, Bird CR, Ray J, et al. (1990). Expression of a truncated tomato polygalacturonase gene inhibits expression of the endogenous gene in transgenic plants. Mol. Gen. Genet. 224: 477-481.

Tanaka Y, Nakamura S, Kawamukai M, Koizumi N, et al. (2011). Development of a series of gateway binary vectors possessing a tunicamycin resistance gene as a marker for the transformation of Arabidopsis thaliana. Biosci. Biotechnol. Biochem. 75: 804-807.

Wang ZY, MacRae EA, Wright MA, Bolitho KM, et al. (2000). Polygalacturonase gene expression in kiwifruit: relationship to fruit softening and ethylene production. Plant Mol. Biol. 42: 317-328.

Watson AA, Alm RA and Mattick JS (1996). Construction of improved vectors for protein production in Pseudomonas aeruginosa. Gene 172: 163-164.

Xu G, Sui N, Tang Y, Xie K, et al. (2010). One-step, zero-background ligation-independent cloning intro-containing hairpin RNA constructs for RNAi in plants. New Phytol. 187: 240-250.

Xu WR, Wang YJ, Wang XP, Hao W, et al. (2005). Construction of the plant expression vectors carrying resistant genes to powdery mildew and adversities in wild species of Vitis in China. Acta Bot. Boreal.-Occident. Sin. 25: 851-857.

Xue GP and Loveridge CW (2004). HvDRF1 is involved in abscisic acid-mediated gene regulation in barley and produces two forms of AP2 transcriptional activators, interacting preferably with a CT-rich element. Plant J. 37: 326-339.

Zhao LX, Lu L, Zhang L, Wang A, et al. (2009). Molecular evolution of the E8 promoter in tomato and some of its relative wild species. J. Biosci. 34: 71-84. 